\title{
Ethics and Education in the Digital Age: Global Perspectives and Strategies for Local Transformation in Catalonia
}

\section{Don Olcott Jr. ${ }^{1}$, Xavier Carrera Farran², Eliana Esther Gallardo Echenique ${ }^{3}$ and Juan González Martínez ${ }^{4}$}

1. Charles Sturt University (CSU), Australia | dolcott@csu.edu.au

2. University of Lleida (UdL), Spain | carrera@pip.udl.cat

3. Rovira i Virgili University (URV), Spain | egallardoechenique@gmail.com

Submitted in: November 2014

4. Rovira i Virgili University (URV), Spain | juan.gonzalezm@urv.cat Accepted in: March 2015 Published in: April 2015

\section{Recommended citation}

Olcott Jr. D., Carrera Farran, X., Gallardo Echenique, E. E., \& González Martínez, J. (2015). Ethics and Education in the Digital Age: Global Perspectives and Strategies for Local Transformation in Catalonia. RUSC. Universities and Knowledge Society Journal, 12(2). pp. 59-72. doi http://dx.doi. org/10.7238/rusc.v12i2.2455

\begin{abstract}
The purpose of this paper is to provide a global analysis and a synthesis of emerging ethical issues, situations, and questions that face educators using digital technologies. The authors offer a conceptual framework centered on the Ethical Context Continuum (ECC) that integrates how society, culture, values, and technology are perceived by people and create ethical choices that consider the potential harm, benefits or both to individuals and groups. A summary of emerging ethical issue areas is discussed and recommendations are offered for adapting global best practices and lessons learned at the local level in Catalonia. The authors conclude that the range and complexity of potential ethical issues relevant to the use of digital technologies will expand in the future. The development of a comprehensive Code of Ethics for the Use of Digital Technologies is strongly recommended across all societal sectors in Catalonia. These proposals and other recommendations can also be applied in other local and national contexts.
\end{abstract}

\section{Keywords}

ethics, technology, society, values 


\section{Ética y Educación en la era digital: perspectivas globales y estrategias para la transformación local en Cataluña}

\section{Resumen}

El propósito de este artículo es proporcionar un análisis global y una síntesis de las nuevas cuestiones y situaciones éticas a las que se enfrentan los educadores que utilizan tecnologías digitales. Se presentará un marco conceptual centrado en el contexto ético continuo (CEC), que integra cómo se perciben la sociedad, la cultura, los valores y la tecnología y cómo se crean opciones éticas teniendo en cuenta los daños y los beneficios potenciales tanto para las personas como para los grupos humanos. Se comentará una síntesis de las áreas temáticas éticas emergentes y se ofrecerán recomendaciones para la adaptación en Cataluña de las mejores prácticas y los principales hitos. Se concluirá afirmando que el alcance y la complejidad de los problemas éticos potenciales relacionados con el uso de las tecnologías digitales se ampliará en el futuro. El desarrollo de un código ético para el uso de las tecnologías digitales es muy recomendable en todos los sectores sociales de Cataluña. Esta y otras recomendaciones que se propondrán podrán aplicarse también a otros contextos locales y nacionales.

\section{Palabras clave}

ética, tecnología, sociedad, valores 


\section{Introduction: ethics, technology and education}

In recent years we have witnessed a revolution in Information and Communication Technologies (ICTs) that has transformed every field of knowledge. Education has not remained detached from this revolution. Ethical questions in relation to technology encompass a wide range of topics, including privacy, neutrality, the digital divide, cybercrime, and transparency. However, when we consider ethics and technology in relation to education, even more questions exist. Education is key to the functioning of a democratic society. Every great political thinker has defended the need for and importance of a quality public education system because this type of system ensures that a society's citizens are educated enough to make decisions in a democratic political system that benefit society as a whole rather than just themselves.

A quality public education system should ensure that both children and adults will, throughout their education, develop key competences such as critical thinking, judgement, and citizenship that will help them to evolve in a democratic society.

In this article, from an ethical perspective and with an eye on the current situation, we discuss the challenges posed by the process involved in integrating digital technologies into education so that education can really contribute to the development of the knowledge society in accordance with any of the approaches suggested by Kozma (2011). More specifically, in this article we aim to:

- analyze the emerging ethical questions and options faced by educators when they use digital technologies, and

- construct a practical and applicable framework that can be adapted to all education sectors in Catalonia.

The article is divided into three sections. In the first section we define the meaning of ethics that we have taken into account and outline the ethical context in which (ethical) decisions affecting the presence of technology in education should be taken. In the second section, we analyze and identify from a global perspective the factors and challenges that arise from the presence of technology in education and that education must take into account when it aims to incorporate technology from an ethical perspective. We also discuss recent recommendations from the European Union and identify Catalonia's strengths in a local context in order to further analyze the incorporation into education of technology-related ethics. In the third section we establish four premises on which all decisions or actions affecting the education-technology binomial should be based and make a series of recommendations that are intended to achieve significant progress in the ethical considerations associated with the presence of technology in education and society.

\section{Conceptual approach based on ethical choice}

The permanent decision-making process that is associated with the inclusion and use of digital technologies in education should be imbued with an ethical examination that justifies the goodness of the acts that derive from them. These decisions and acts take place in a global and at once local environment where values, people and technologies converge. 


\subsection{Defining ethics and ethical choice}

Rhodes (1986, p. 21) defined ethics as "the systematic exploration of questions about how we should act in relation to others". A related concept to this is ethical sensitivity, which refers to the conscience of an individual (and by extension that of an organization) whose actions may affect the welfare of others (Bebeau, Rest \& Yamoor, 1985). In this context, ethics involve: (1) determining whether the technological options directly or indirectly affect another person negatively; (2) developing an ideal plan of action; (3) identifying the important values associated with each situation; and (4) implementing a solution or specific plan of action that will be monitored and evaluated (Rest, 1982).

Jonas (1995) suggested that, regardless of the field or specialty, responsibility should be the guiding principle of technological actions. Every one of us should modulate our use of technology by taking into account that: (1) personal responsibility goes beyond formal and legal responsibility and is linked to other values and moral principles; (2) we are responsible for our actions and the consequences of our actions; and (3) before acting, we should always anticipate and predict the effects of our actions (Jonas, 1995).

University education is not exempt from these issues. For example, would selling data on students enrolled on a $\mathrm{MOOC}$ to potential employers by the MOOC providers be an ethically appropriate decision? Some important MOOC providers are actually considering this option as an income-generation strategy (despite the rhetoric that MOOCs are essentially free). This is one example of an ethical question whose responses lie within the "gray zone". This gray zone is the normal ethical context since real ethical implications are scattered along an ethical context continuum. If MOOC providers obtain the informed consent of their students to sell student data to potential employers, does this eliminate the potential harm to students and, if so, is it ethically correct? Traditionally, open universities were created to expand access to higher education to individuals who historically were unable to attend. Will students be obliged to choose to enroll in open university courses even though their university leads them to failure? Is this ethically correct (Kelly \& Mills, 2007)?

\subsection{Ethical choices and the Ethical Context Continuum (ECC)}

One of our first objectives is to examine the ethical options existing in the education sector that are related to innovation and the use of digital technologies. Figure 1 illustrates the conceptual focus for this definition of ethical choices.

Figure 1 suggests that ethical choices occur along an ethical context continuum (ECC) and are inherently influenced by the social and cultural norms prevalent where they occur and by the values people hold in a society or culture. It is people - the agents of technology in any of their guises (producers, managers, receivers or users) who display behaviors that are either exemplary and exemplifying or reprehensible, irresponsible or illicit. People's ability to analyze, reflect, and constantly ask themselves questions, together with their imagination, ingenuity and creativity - not to mention their curiosity, attitude and will - drive them into action both individually and collectively. Also, when ethical concerns arise, they are not black and white but appear along the ECC. If we bear in mind the key variable in our definition of ethics (the perception of harm done to third parties), the ECC enables an evaluation of the situation, issue or question that identifies whether that situation, issue or question is perceived as being potentially harmful to others, neutral, or beneficial to others. The ECC recognizes that the consistency of these issues with culture and normative values contributes to the way in which society responds in its choices and ethical points of view. 
Figure 1. Ethical Context Continuum and the ethical choices in education

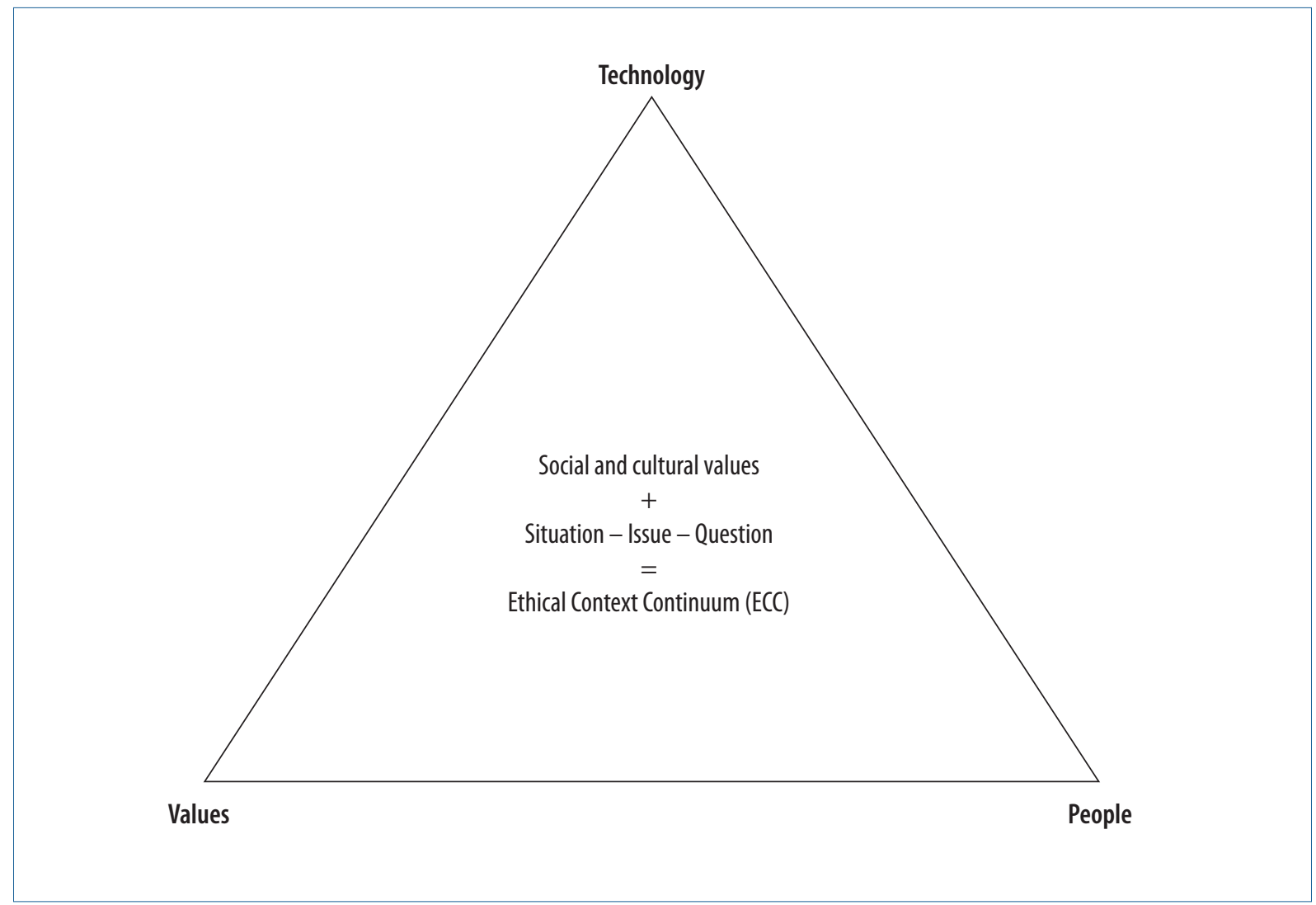

\section{The global and local perspectives and the context for ethics and technology}

From the global perspective we analyze the factors, challenges and recent recommendations that, when added to the strengths that exist in the local Catalan context, provide enough elements to incorporate the ethical dimension into decisions that affect the presence of technology in education.

\subsection{Factors}

The adoption and use of ICTs around the world are now ubiquitous (Marginson, 2009, 2010; Olcott, 2009, 2012). As well as these transformations we are also witnessing an accelerated change that is creating both new challenges and new opportunities for educators along the ECC. The context is expanding at the same time that a series of emerging factors are generating potential ethical problems among educators. Below we describe these emerging factors.

Globalization may be defined as the worldwide flow of people, technology, economics, ideas, knowledge and culture. Internationalization, due to its focus on the relationships between nations, people and cultures (Knight, 2005), may be taken to be a component of globalization. Globalization is obliging education leaders to redefine the international dimensions of their institutions. It is also expanding the issues located along the ethical context continuum and presenting new questions and situations for educators. 
Digitization, which is characterized by rapid advances in communication technologies, is producing a rapid and efficient exchange of knowledge and information that can take place anywhere and anytime. This extension of the cybernetic highway involves a greater level of complexity through social institutions in the political, economic, social, cultural and educational spheres. Differing approaches in business, education, commerce, and governmental relations require new dimensions in both the practical and ethical contexts.

Competition is intensifying and new business agents with different roles, missions and strategies are entering the education sector in search of financial gain.

Public-private partnerships are increasing in direct response to this new global market and to the Open Content Movement (OERs and MOOCs, etc.). The acceptance of knowledge as a worldwide public good that should be easily and freely accessible to all is gaining impetus.

The quality of education (especially in e-learning) is being questioned due to the massive influx of new providers. National regulatory agencies and accreditation bodies are supervising the "qualifications factories" and educational practices of these providers.

All the above factors have helped to shape an educational panorama that creates both opportunities and challenges along the ECC. Our traditional values, attitudes and ethical perceptions are constantly being challenged and we are obliged to question our traditional values and beliefs on education. The incursion of ICTs into education therefore involves new ethical challenges, new questions and new issues.

\subsection{Challenges}

The challenges outlined below affect people both individually and collectively and range from digital identity and reputation to the critical use of information, ICT-related abuse and online security and privacy.

Digital identity is defined as "information related to a person that is available on the internet (personal data, images, files, news, comments and so on), setting out a personal description at the digital level" (INTECO, 2012, p. 5). Not only does this trail of information configure the digital identity of a person, group or organization but it also enables others to use that information to construct a shared social opinion of others and build someone's reputation.

The boundaries between human beings' real and digital spaces: thresholds and invasions. Lévy (1999) analyzed how transfer between the actual (real) and the virtual (online) is produced, describing it as a transformation from one way of being to another. According to Lévy (1999), the virtual does not imply falseness, illusion or fiction but a new way of being that fosters creative processes beyond what is allowed by physical presentiality.

Online security (of an individual, a group, an organization or an administration) becomes a challenge that may determine the stability and smooth operation of the system itself. Although a greater level of sensitivity and concern for the secure use of the Internet are being observed, a lack of knowledge, information and care on the part of users makes them vulnerable to risks ranging from data loss to theft of digital identity. Training programs are needed in order to reverse this situation and promote good habits regarding the use of technology and the networks.

Online bullying both inside and outside the school context has, via technology, discovered new forms of attack that transcend the school environment and enable the privacy of the bullied child or youth to be constantly invaded. Whether receivers or perpetrators, schoolchildren are victims of various forms of online bullying (including cyberbullying, sexting, trolling, and happy slapping) that go beyond the school context and disturb their psychological and personal development (Patchin \& Hinduja, 2006). 
Use and abuse of ICTs in school and family contexts. Though they may not reach the level of techno-addiction, some people develop behaviors that reflect an anomalous and excessive use of technology (Charlton \& Danforth, 2007). The non-self-regulated use of technology can affect and condition personal relationships and interactions, especially those of young people who need to feel permanently connected to the Internet (Cuesta \& Gaspar, 2013) or fear being disconnected from their peers (Przybylski, Murayama, Dehaan \& Gladwell, 2013).

Judicious and reasonable consumption and use of technology. In response to the excessive use of technology, proposals have been made to provide education that promotes healthful habits with regard to the amount of time one should spend using technology. With this approach, it is the users themselves who should regulate and self-manage their access to technologies efficiently. Seen from another perspective, this judicious use of technology is related to media literacy, which derives from the convergence on the Internet of all traditional means of communication.

Plagiarism in education. Using the ideas, words and works of others as if they were one's own is recognized in academic environments as academic plagiarism. However, plagiarism is not always intentional or malicious. Sometimes it is done unwittingly and is caused by a lack of prior training. Agud (2014) states that some university students admit committing plagiarism and other forms of academic fraud and warns against such malpractices since they can be the prelude to fraudulent practices during the professional careers of those involved.

Intellectual property in the digital context. The COIT (2014) report corroborated that the inrush of digital technology has enabled access to the storage, recording, reproduction and dissemination of content on a massive scale, thereby making it difficult to dovetail copyright and the commercial exploitation of digital works and productions. Created in response to the traditional form of commercial protection via copyright, which protects financial benefit, the proliferation of online copyleft licenses for digital works (especially Creative Commons) highlights the tension between the commercial and the social views regarding the use and exploitation of the Internet.

Dissemination of information and the sharing of knowledge on the Internet. Universal dissemination of information does not guarantee its quality or veracity. However, it does help to produce more aware and autonomous individuals and make it difficult for governments, economic powerhouses and media conglomerates to act with impunity. On the Internet the unidirectional communications model of traditional media has given way to more open and participative models in which individuals, acting anonymously and altruistically on an endless range of environments and networks, share information and knowledge with others, thus allowing for collaboration and the collective construction of knowledge.

\subsection{Recommendations}

The report by the European Group on Ethics (EGE) on the Ethics of Information and Communication Technologies (Salvi, 2012) aimed to provide a point of reference for the Digital Agenda for Europe, the EU's strategic plan to enable digital technologies (including the Internet) to help achieve sustainable economic growth. The plan was drawn up in response to the need to safeguard the EU's fundamental values, which are: (1) respect for human dignity; (2) respect for freedom; (3) respect for democracy, citizenship and participation; (4) respect for privacy; (5) respect of autonomy and informed consent; (6) justice; and (7) solidarity (Salvi, 2012, p. 60). These values guide both the policies of the EU in general and those pertaining to its Digital Agenda.

The EGE report highlights the importance of responsibility and individual conscience (Dratwa, 2014) and determines the need for more education and greater public awareness in general. Individuals should be equipped 
with the tools they need to: (1) protect their data and privacy; (2) be alert, aware and informed; and (3) be conscious of the consequences when signing exemptions of privacy or sharing their data. Therefore, education must also enter into a broad social dialogue on the implications of new technologies for privacy, autonomy and liberty. Education must promote greater knowledge and reflection with regard to the practical and moral dimensions of these aspects in every curriculum in the EU.

\subsection{Strengths}

Catalonia has presented successful, consolidated experiences and initiatives that help to narrow the digital divide. One of these successful and valuable initiatives is the Xarxa Òmnia (Òmnia network) (http://xarxa-omnia.org), which was set up by the Generalitat de Catalunya (autonomous government of Catalonia) in 1999 and currently contains over a hundred Òmnia points distributed across Catalonia. Each of these points is a telecenter that promotes technology-based learning methods, the social integration of individuals who are at risk of social exclusion, and online community services.

The Mobile World Capital Barcelona Foundation (http://mobileworldcapital.com), in alignment with the global and European agenda, believes that mobile technologies are an opportunity for change in areas such as mHealth, mEducation and mSmartCities. Since 2013, mSchools has gathered public and private institutions to promote mobile education, opening up new forms of teaching and learning that improve performance and employability. mSchools helps students to acquire important new digital competences and prepare them for the world of today. mSchools Mobile4all, an initiative designed to narrow the digital divide, promotes accessibility to mobile devices for students with disabilities and their families.

Internet Segura (http://www.internetsegura.cat/index.php), another impact experience for children and youngsters, is a component of the Safer Internet program of the European Commission. In Catalonia the organization responsible for this initiative, which enjoys the participation of the Mossos d'Esquadra (the Catalan regional police force), is CESICAT (https://www.cesicat.cat/). The main objectives are to: (a) promote the safe and responsible use of the Internet, devices and applications and prevent harmful contact, behaviors and contents; and (b) make resources and materials available for children, families and teachers. In 2013, 3,547 experts disseminated Internet Segura to 109,568 participants at teaching centers throughout Catalonia (Mossos d'Esquadra, 2014), which illustrates the intense level of prevention conducted.

The autonomous government of Catalonia also makes available (to every agent of education) numerous digital repositories of educational resources, including: CREA (http://www.edu365.cat/crea/), which comprises a selection of web 2.0 tools to promote multimedia communication, collaborative work, and the completion of projects; Alexandria (http://alexandria.xtec.cat/), a web service for distributing educational materials and promoting the intensive use of digital technologies; and Edu3.cat (http://www.edu3.cat/), a pioneering education portal for radio and television that is now a reference in Europe and that comprises an endless supply of audiovisual resources for teachers and other education professionals. 


\section{Conclusion: Towards the convergence of ethics, technology and education}

It is highly likely that the potential ethical problems will remain complex in the future. The current movement towards content and knowledge as a global public good could expand the access and opening up of education exponentially, a step that would bring with it a great deal of ethical questions, situations and questions that have not yet even been considered. Our concern for the technology = progress axiom notwithstanding, these innovations provide many positive opportunities for our lives and our communities.

We believe that the following premises are valuable principles for action that should be taken into consideration when any decisions on the use of ICTs in the educational and social environments are taken by governments, companies, organizations, technicians, politicians, teachers, educators, or private citizens.

- Premise 1. Training in the responsible, secure and ethical use of technologies must reach all members of society.

All individuals must be given quality training in accordance with their needs, interests, abilities and skills. All individuals require attention, especially those in the less-privileged social groups who find themselves digitally excluded. This attention should continue until the situation is reversed.

- Premise 2. Education is based on values, and education is provided in, with and from values.

Education in the ethical, responsible and safe use of digital technologies is not viable if values are not constantly and explicitly present in all education initiatives. Only by constructing individual and collective values in each and every child, adolescent and youth is it possible to create an ethically mature society. This training in values should be extended to the entire life cycle of all individuals.

- Premise 3. Technologies should be used appropriately (judiciously and respectfully), not just used.

The appropriate use of technologies responds to criteria of sustainability, regulated consumption, respect for people and their rights, the satisfaction of basic needs (including education, communication and social involvement), and personal and collective well-being. Any excessive, inappropriate or harmful use, management or development of these technologies that negatively affects people immediately or in the future should be rejected.

- Premise 4. Individual and collective commitment determines the responsible and exemplary use of technologies.

This commitment: (a) is based on values and duties; (b) requires awareness of one's use of technologies and of the consequences of one's decisions and actions; and (c) is made when an individual or group systematically makes a decision about technology and uses this technology in accordance with their answers to questions such as: how does my using it make me better?, how do it improve my performance?, how does it benefit and how is it detrimental to others?, how does it help others?, and what does it give to society?

Below we present a series of preliminary recommendations for policymakers and educators that are aimed at achieving progress in the ever-changing field of techno-ethics:

- Integrate global perspectives, best practices and lessons learned on the ethical uses of digital technologies so that they align with the cultural, social and ethnic norms of the community and of society in general.

- Adapt and apply the recommendations made in the EGE (European Group on Ethics) report locally in public dialogue, education policy and government supervision. 
- Promote the adoption and use of the Ethical Context Continuum (ECC) to facilitate dialogue between and commitment from local educators, businesspeople, community professionals, parents and government leaders regarding all potential ethical problems.

- Promote programs on the safe and responsible use of digital technologies directed at all groups and social sectors with deficiencies, shortages or specific problems.

- Develop and distribute a Code of conduct or Code of techno-ethics on the use of digital technologies that reaches out to a broad section of the community (education, business, government, services, and even religious organizations).

- Identify technologically responsible teaching centers. Recognize their work in society and extend this recognition to all entities, organizations or groups that demonstrate a responsible use of ICTs.

- Train, to an optimal level of digital competence, all professionals who participate in training, prevention and intervention programs on the correct use of digital technologies. In all cases include the ethical dimension of this competence in accordance with the functions and responsibilities of each professional.

- Help to define specific norms similar to those that are aimed at ensuring the quality of school textbooks.

- Involve teachers and education specialists in the development of educational technology (developers and engineers often work behind closed doors when developing their products).

- Revise teacher training programs to ensure that they include the positive use of education technologies.

- Introduce specific programs to eradicate plagiarism and academic fraud at teaching centers.

- Finance and directly support the development of education technology and ensure that it is free from commercial interests.

- Clearly define the scope of the use of digital technology in education. Identify where it provides added value and where it does not. Take special care to ensure that children and adults who are vulnerable are protected from unethical practices that use technology.

- Ensure that technology is not only adapted to education but that it is understood and used responsibly. Among other initiatives to promote the responsible use of technology, ensure that school curriculums promote awareness and reflection on the notion of privacy. Ensure that they provide information on personal data protection in a digital environment and that they discuss the tools available for ensuring this protection.

- Create an Observatory on the responsible use of technologies in Catalonia that will implement some of these recommendations as well as other specific ones such as: draw an exhaustive map of existing good practices in the region regarding the responsible use of technologies; compile and disseminate specific online resources to promote responsible use; and carry out actions aimed at promoting greater awareness among the citizens.

The power and potential of digital technologies are only surpassed by the power and potential of human beings. Ethical choices are made by people, communities, governments, companies, universities and societies. We all have a collective responsibility to ensure that the benefits derived from these innovations eradicate and control their negative uses and abuses in a balanced way. Politicians and educators have a fundamental role to play in educating the entire population in the appropriate uses of these innovations. 


\section{Acknowledgment}

The authors would like to thank the following researchers and experts, without whose contribution this paper would not have been possible: Jim Dratwa and Joanna Parkin (European Commission), Martin Schmalzried (Confederation of Family Organizations in the European Union), Josep Maria Duart Montoliu (Open University of Catalonia), Victoria Camps Cervera (Autonomous University of Barcelona), Eugenia Carmona Garcia (Mossos d'Esquadra (regional police force) of the autonomous government of Catalonia) and Ramon Arnó Torrades (lawyer specializing in legal aspects of the Information Society.

\section{References}

Agud, J. L. (2014). Fraude y plagio en la carrera y en la profesión. Revista Clínica Española, 7, 410-414. doi: http://dx.doi.org/10.1016/j.rce.2014.03.007

Bebeau, M. J., Rest, J. R., \& Yamoor, C. M. (1985). Measuring dental students ethical sensitivity. Journal of Dental Education, 49(4), 225-235.

Charlton, J. P., \& Danforth, I. D. W. (2007). Distinguishing addiction and high engagement in the context of online game playing. Computers in Human Behavior, 23(3), 1531-1548. doi: http://dx.doi.org/10.1016/j. chb.2005.07.002

Colegio Oficial de Ingenieros de Telecomunicación (COIT). (2014). La gestión de derechos de propiedad intelectual en el entorno TIC (Executive Report). Madrid. Retrieved from http://www.coit.es/descargar.php?idfichero=9442

Cuesta, U., \& Gaspar, S. (2013). Análisis motivacional del uso del smartphone entre jóvenes: Una investigación cualitativa. Historia y Comunicación Social, 18, 435-447.

Dratwa, J. (2014). Ethics of security and surveillance technologies (EGE Opinion Report No 28). Luxembourg: Publications Office of the European Union. Retrieved from the website of the European Group on Ethics in Science and New Technologies (EGE) to the European Commission: http://ec.europa.eu/bepa/european-group-ethics/docs/ publications/ege_opinion_28_ethics_security_surveillance_technologies.pdf

Instituto Nacional de Tecnologías de la Comunicación (INTECO). (2012). Guía para usuarios: identidad digital y reputación online. Madrid. Retrieved from http://www.inteco.es/guias_estudios/guias/Guia_Identidad_ Reputacion_usuarios

Jonas, H. (1995). El principio de responsabilidad. Ensayo de una ética para la civilización tecnológica. Barcelona: Herder. Kelly, P., \& Mills, R. (2007). The ethical dimensions of learner support. Open Learning: The Journal of Open, Distance and E-Learning, 22(2), 149-157. doi: http://dx.doi.org/10.1080/02680510701306699

Kozma, R. B. (2011). A framework for ICT policies to transform education. In: United Nations Educational Scientific and Cultural Organization (UNESCO) (Ed.), Transforming education: The power of ICT policies (pp. 19-36). Paris: UNESCO,

Knight, J. (2005). Borderless, offshore, transnational and cross-border education: Definition and data dilemmas (Report for Observatory on Borderless Higher Education). London, UK: The Observatory on Borderless Higher Education. Retrieved from http://trove.nla.gov.au/version/39317912

Lévy, P. (1999). ¿Quées lo virtual? Barcelona: Paidós. 
Marginson, S. (2009). The limits of market reform in higher education. Paper presented at the Institute for Higher Education (RIHE). Hiroshima, Japan: Hiroshima University. Retrieved from http://www.cshe.unimelb.edu.au/ people/marginson_docs/RIHE_17Aug09_paper.pd

Marginson, S. (2010). Creating global public goods. Opening keynote for a seminar on the Global University. Virginia, USA: University of Virginia. Retrieved from http://www.cshe.unimelb.edu.au/people/marginson_docs/ UVA_141110_version 2.pdf

Mossos d'Esquadra (2014). Mossos d'Esquadra ofereixen 3.547 xerrades sobre internet segura al Ilarg del 2013 amb més de 109.500 assistents [In 2013 the Mossos d'Esquadra (Catalan regional police force) gave 3,547 talks on Internet safety to over 109,500 people]. Retrieved from http://premsa.gencat.cat/pres_fsvp/AppJava/ notapremsavw/detall.do?id=246874

Olcott Jr., D. (2009). Going global: Trends in cross border higher education for ODL. China Journal of Open Education Research, 15(4), 4-9.

Olcott Jr., D. (2012). OER perspectives: Emerging issues for universities. Distance Education, 33(2), $283-290$. doi: http://dx.doi.org/10.1080/01587919.2012.700561

Patchin, J. W., Hinduja, S. (2006). Bullies move beyond the schoolyard: A preliminary look at cyberbullying. Youth Violence and Juvenile Justice, 4(2), 148-169. doi: http://dx.doi.org/10.1177/1541204006286288

Przybylski, A. K., Murayama, K., DeHaan, C. R., \& Gladwell, V. (2013). Motivational, emotional, and behavioral correlates of fear of missing out. Computers in Human Behavior, 29(4), 1841-1848. doi: http://dx.doi.org/10.1016/j. chb.2013.02.014

Rest, J. R. (1982). A psychologist looks at the teaching of ethics. The Hasting Center Report, 12(1), 29-36. doi: http://dx.doi.org/10.2307/3560621

Rhodes, R. (1986). The making of the atomic bomb. New York: Simon and Schuster.

Salvi, M. (2012). Ethics of information and communication technologies (EGE Opinion Report No 26). Luxembourg: Publications Office of the European Union. Retrieved from the website of the European Group on Ethics in Science and New Technologies (EGE) of the European Commission: http://ec.europa.eu/bepa/european-groupethics/docs/publications/ict_final_22_february-adopted.pdf 


\title{
About the authors
}

Don Olcott Jr.

dolcott@csu.edu.au

ORCID ID: http://orcid.org/0000-0003-4542-9305

Professor of Educational Leadership and ODL and Co-Director, ulmagine Digital Learning Lab,

Charles Sturt University (CSU), Australia

Doctor of Education and Professor of Educational Leadership and ODL at Charles Sturt University (CSU) Australia. EDEN Fellow, former Chief Executive of The Observatory on Borderless Higher Education (London), and 2014 Individual Prize of Excellence recipient from the International Council of Open and Distance Education (ICDE). 2014 inductee to the United States Distance Learning Association (USDLA) Hall of Fame.

Division of Student Learning

ulmagine Digital Learning Lab

Building 29/Locked Bag 588

Boorooma Street

Wagga Wagga 2650

New South Wales

Australia

\author{
Xavier Carrera Farran \\ carrera@pip.udl.cat \\ ORCID ID: http://orcid.org/0000-0003-3420-4215 \\ Universitat de Lleida \\ Departament de Pedagogia i Psicologia \\ Av. Estudi General, 4 \\ 25001 Lleida \\ Spain
}

Tenured professor in the Department of Pedagogy and Psychology at the University of Lleida (UdL), Spain

Holds a PhD in Psychopedagogy. Tenured professor in the Department of Pedagogy and Psychology at the University of Lleida. Member of the COMPETECS (competences, education, technology and society) research group (ref. 2014SGR1611).

\section{Eliana Esther Gallardo Echenique \\ Universitat Rovira i Virgili \\ Carretera de Valls, s/n \\ Campus Sescelades \\ 43007 Tarragona \\ Spain}

egallardoechenique@gmail.com

ORCID ID: http://orcid.org/0000-0002-8524-8595

Member of the Applied Research Group in Education and Technology (ARGET) of the Rovira i Virgili University (URV), Spain

Holds a PhD in Educational Technologies and a Degree in Communication Sciences. She was a specialist and consultant in education technologies at the Peruvian Ministry of Education for almost ten years. She is a member of ARGET (Applied Research Group in Education and Technology, ref. 2014SGR1399). 


\section{Juan González Martínez}

juan.gonzalezm@urv.cat

ORCID ID: http://orcid.org/0000-0002-9175-6369

Coordinator of the Master's in Educational Technology: e-Learning and Knowledge Management of the Rovira i Virgili University (URV), Spain

Holds a PhD in Educational Technology and a PhD in Hispanic Studies. He is the coordinator of the Master's in Educational Technology: E-learning and Knowledge Management of the Rovira i Virgili University (URV). Member of ARGET (Applied Research Group in Education and Technology; ref. 2014SGR1399) and L@TE (Laboratory for Technology Applied to Education)

Universitat Rovira i Virgili

Av. de Remolins, 13-15

Campus Terres de l'Ebre

43500 Tortosa

Spain

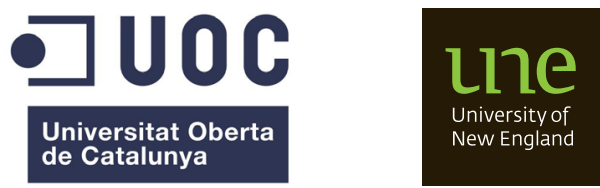

